\title{
Analisis Rumah Tangga Miskin Di Kabupaten Lebong
}

Siti Zuliana Fedi

Badan Pusat Statistik (BPS) Kabupaten Lebong, siti.zf@bps.go.id

\begin{abstract}
ABSTRAK, Fenomena kemiskinan melanda hampir di semua wilayah Indonesia termasuk Kabupaten Lebong, Provinsi Bengkulu. Selama dua tahun terakhir, kemiskinan di Kabupaten Lebong selalu mengalami peningkatan. Namun, anggaran perlindungan sosial dalam mengentaskan kemiskinan secara nasional selalu mengalami peningkatan. Penelitian ini bertujuan untuk mencari faktor-faktor yang mempengaruhi kecenderungan rumah tangga untuk menjadi miskin di Kabupaten Lebong. Metode analisis yang digunakan adalah PCA Polychoric dan Regresi Logistik Biner. Dihasilkan bahwa kecenderungan rumah tangga di Kabupaten Lebong unuk menjadi miskin dipengaruhi oleh variabel kepemilikan aset, proporsi ART yang bekerja, proporsi ART berpendidikan tinggi, dan Jumlah ART. Dimana semakin tinggi nilai variabel-variabel penelitian tersebut yang dimiliki suatu rumah tangga, maka semakin kecil peluang rumah tangga untuk menjadi miskin.
\end{abstract}

Kata Kunci: kabupaten lebong, kemiskinan, pca polychoric, regresi logistik biner.

\section{PENDAHULUAN}

Fenomena kemiskinan terjadi hampir di setiap wilayah Indonesia tak terkecuali di Kabupaten Lebong, Provinsi Bengkulu. Kemiskinan memiliki definisi sebagai ketidakmampuan dari sisi ekonomi untuk memenuhi kebutuhan dasar makanan dan bukan makanan yang diukur dari sisi pengeluaran menggunakan konsep kemampuan memenuhi kebutuhan dasar (basic needs approach) $)^{[3]}$. Sehingga, penduduk miskin adalah penduduk yang memiliki rata-rata pengeluaran perkapita perbulan dibawah garis kemiskinan. Menurut Cristianto dalam Zuhdiyaty (2017) Kemiskinan suatu daerah merupakan cerminan dari tingkat kesejahteraan penduduk di daerah tersebut ${ }^{[1]}$. Semakin banyak penduduk yang divonis miskin di suatu daerah, mengindikasikan bahwa tingkat kesejahteraan daerah tersebut semakin rendah.

Sebagaimana yang tercantum pada Sustainable Development Goals (SDGs) bahwa penghapusan kemiskinan menjadi tujuan utama para pemimpin dunia. Hal ini membuat setiap pemimpin baik tingkat nasional, provinsi, maupun level yang lebih rendah, bersama-sama menerapkan berbagai kebijakan dalam mengentasan kemiskinan. Salah satu cara Indonesia dalam mempercepat mengentaskan kemiskinan adalah dengan adanya program perlindungan sosial seperti Program Keluarga Harapan $(\mathrm{PKH})$, bantuan pangan, Program Indonesia Pintar (PIP), Program Indonesia Sehat, dll. Tercatat bahwa besaran anggaran perlindungan sosial yang telah dialokasikan oleh pemerintah setiap tahunnya terbilang banyak dan terus meningkat. Pada tahun 2020, dana alokasi untuk perlindungan sosial adalah sebesar 372,5 triliun rupiah yang meningkat satu persen dari alokasi perlindungan sosial tahun 2019.

Meskipun demikian, berbagai kebijakan yang telah dibuat ternyata belum maksimal dalam menurunkan kemiskinan di beberapa daerah termasuk di Kabupaten Lebong yang selama dua tahun terakhir justru mengalami peningkatan angka kemiskinan. Berdasarkan data Badan Pusat Statistik (BPS), Kabupaten Lebong menempati posisi ke- 7 termiskin di Provinsi Bengkulu pada tahun 2020 dengan tingkat kemiskinan 11,85 persen. Selama dua tahun terakhir sejak 2018 (2019-2020) tingkat kemiskinan di Kabupaten Lebong selalu mengalami peningkatan dibandingkan periode sebelum 2018 hal ini terlihat dari Grafik 1 dibawah ini.

\section{Grafik 1. Tingkat Kemiskinan Kabupaten Lebong Tahun 2015-2020}

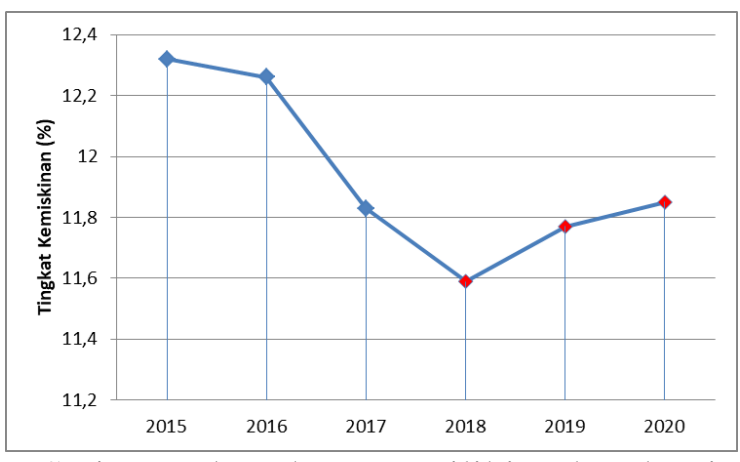

Setiap daerah memiliki karakteristik penduduk yang berbeda-beda, khususnya karakteristik yang dimiliki oleh penduduk miskin. Sehingga, terkadang suatu kebijakan 
pemberantasan kemiskinan berpengaruh besar pada penurunan angka kemiskinan di suatu daerah, namun di daerah lain, kebijakan tersebut justru kurang efektif bahkan bisa jadi tidak berpengaruh. Sehingga penting bagi setiap pengambil kebijakan untuk mengetahui faktor apa saja yang dapat mempengaruhi tingkat kemiskinan di daerahnya. Selain itu, kemiskinan merupakan masalah multidimensi yang tidak hanya mencakup aspek ekonomi rumah tangga saja, melainkan aspek sosial, budaya, politik, dan partisipasi dalam masyarakat ${ }^{[2]}$.

Pada umumnya kemiskinan terjadi pada level rumah tangga. Oleh karena itu, pada penelitian ini, karakteristik yang digunakan bukanlah karakteristik yang hanya diwakili oleh kepala rumah tangga saja, melainkan karakteristik yang melekat di dalam rumah tangga secara keseluruhan.

\section{TINJAUAN PUSTAKA}

\section{KEMISKINAN}

Menurut Badan Pusat Statistik (BPS), Kemiskinan memiliki definisi sebagai ketidakmampuan dari sisi ekonomi untuk memenuhi kebutuhan dasar makanan dan bukan makanan yang diukur dari sisi pengeluaran menggunakan konsep kemampuan memenuhi kebutuhan dasar (basic needs approach) [3]. Penduduk miskin adalah penduduk yang memiliki rata-rata pengeluaran perkapita perbulan dibawah garis kemiskinan. Marlinda (2019) dalam penelitiannya membagi status ekonomi rumah tangga berdasarkan tingkat kuintil pengeluaran perkapita perbulan, dimana rumah tangga pada kuintil pertama digolongkan sebagai rumah tangga termiskin ${ }^{[4]}$. Pada penelitian ini juga, rumah tangga miskin adalah rumah tangga yang berada pada kelompok kuintil pertama pengeluaran perkapita perbulan.

Berdasarkan hasil penelitian terdahulu, faktor-faktor yang mempengaruhi kemiskinan suatu rumah tangga diantaranya adalah pendapatan, jumlah anggota keluarga, dan pendidikan ${ }^{[5]}$. Pada penelitian lain menyebutkan pula bahwa pendidikan dan kepemilikan aset dapat mempengaruhi kemiskinan suatu rumah tangga ${ }^{[6]}$.

\section{PRINCIPAL COMPONENT ANALYSIS (PCA) POLYCHORIC}

PCA atau analisis komponen utama adalah suatu metode statistik yang digunakan untuk menggabungkan beberapa variabel ke dalam satu pengukuran yang lebih sederhana tanpa menghilangkan variasi dari variabel awal. Dimisalkan Vektor acak $\mathbf{X}=(X 1, X 2, \ldots, X p) \boldsymbol{T}$ memiliki matriks varians-kovarians $\Sigma$ dengan nilai akar ciri (eigenvalue) yaitu $\lambda 1 \geq \lambda 2 \geq \cdots \geq \lambda p \geq 0$. Maka model komponen utama ke-i secara umum dapat ditulis sebagai berikut:

$$
Y i=\boldsymbol{e i}^{\prime} \boldsymbol{X}
$$

Komponen yang pertama merupakan kombinasi linier dengan nilai varian yang paling tinggi. dan begitu seterusnya. Metode PCA dalam penelitian ini akan digunakan untuk mencari penimbang bagi variabel kepemilikan aset yang terdiri dari 7 jenis aset. Penambahan kata polychoric pada model PCA dikarenakan matriks korelasi yang digunakan adalah matriks korelasi polychoric yaitu korelasi antara dua variabel berjenis kategorik dua kategori.

\section{PEMODELAN REGRESI LOGISTIK BINER}

Regresi logistik biner merupakan metode untuk mencari hubungan antara variabel dependen $(y)$ yang bersifat biner atau dikotomus $(1=$ sukses, $0=$ gagal $)$ dan variabel prediktor $(\mathrm{x})$ yang bersifat polikotomus ${ }^{[7]}$. Secara umum model regresi logistik biner dapat ditulis:

$$
\pi(x)=\frac{\exp \left(\beta_{0}+\beta_{1} x_{1}+\cdots+\beta_{p} x_{p}\right)}{1+\exp \left(\beta_{0}+\beta_{1} x_{1}+\cdots+\beta_{p} x_{p}\right)}
$$

Bentuk di atas merupakan bentuk tidak linier dari model regresi logistik biner. Model tersebut dapat dilinierkan dengan mentransformasi model tersebut, sehingga menjadi:

$$
\pi(x)=\ln \left[\frac{\pi(x)}{1-\pi(x)}\right]=\beta_{0}+\beta_{1} x_{1}+\cdots+\beta_{p} x_{p}
$$

Untuk setiap variabel dependen $(y), \pi(x)$ adalah peluang kejadian "sukses" atau $y=1$ dengan nilai $x$ tertentu $^{[7]}$. 


\section{METODOLOGI}

Data yang digunakan adalah data sekunder yang berasal dari Badan Pusat Statistik (BPS) hasil Survei Sosial Ekonomi Nasional (Susenas) Maret tahun 2020 di Kabupaten Lebong yang berjumlah 549 rumah tangga sampel. Metode analisis yang digunakan adalah analisis regresi logistik biner dengan variabel dependen adalah miskin (1) dan tidak miskin (0). Dimana rumah tangga miskin pada penelitian ini adalah rumah tangga pada kelompok pengeluaran kuintil 1. Sedangkan variabel independen adalah (1) skor kepemilikan aset (dihasilkan dengan menggunakan metode PCA Polychoric) yang mencakup kepemilikan 7 jenis aset berupa tabung gas $5.5 \mathrm{Kg}$ atau lebih (a), Lemari Es (b), Komputer/Laptop (f), Emas/perhiasan minimal 10 gr (g), Sepeda Motor (h), Mobil (k), Televisi layar datar minimal 30 inch (l), dan tanah/lahan (m); (2) variabel kedua yaitu proporsi anggota rumah tangga (ART) bekerja; (3) variabel ketiga proporsi ART berpendidikan tinggi (minimal berpendidikan SMA); dan (4) variabel keempat adalah jumlah ART yang berbentuk kategori $(1=$ ART lebih dari 4, dan $0=$ ART maksimal 4)

\section{Prosedur Analisis}

Langkah-langkah analisis data dalam penelitian ini yaitu :

1. Penentuan rumah tanga miskin berdasarkan pembagian kuintil menjadi 5 kuintil.

2. Menghitung skor kepemilikan aset setiap rumah tangga menggunakan metode Principal Component Analysis (PCA) Polychoric. Digunakan metode ini agar didapatkan penimbang yang sesuai untuk setiap jenis aset.

3. Membentuk model regresi logistik biner.

4. Menganalisis faktor-faktor yang mempengaruhi rumah tangga miskin di Kabupaten Lebong berdasarkan model yang terbentuk.

\section{PEMBAHASAN}

\section{Penentuan rumah tangga miskin dengan metode kuintil}

Tabel 1 Statistik Pengeluaran Per Kapita Per Bulan menurut Kuintil

\begin{tabular}{|c|c|c|c|c|c|}
\hline Quintile5 & $\mathrm{N}$ & \% of Total N & Minimum & Maximum & Mean \\
\hline$(1)$ & $(2)$ & $(3)$ & $(4)$ & $(5)$ & $(6)$ \\
\hline 1.00 & 110 & $20.0 \%$ & 237357.14 & 552348.38 & 452866.2887 \\
\hline 2.00 & 110 & $20.0 \%$ & 553178.57 & 767559.37 & 656435.7412 \\
\hline 3.00 & 110 & $20.0 \%$ & 768350.48 & 1014247.02 & 890349.1281 \\
\hline 4.00 & 110 & $20.0 \%$ & 1014781.59 & 1349464.70 & 1169906.9544 \\
\hline 5.00 & 109 & $19.9 \%$ & 1352021.49 & 5053798.41 & 1802395.1445 \\
\hline Total & 549 & $100.0 \%$ & 237357.14 & 5053798.41 & 992918.8764 \\
\hline
\end{tabular}

Pengelompokkan rumah tangga miskin dengan metode kuintil yaitu dengan mengelompokkan rumah tangga menjadi lima kelompok dengan kelompok 1 sebagai kelompok paling miskin ${ }^{[8]}$. Metode kuintil membagi data menjadi 5 bagian dimana setiap bagian mencakup lebih kurang 20 persen dari seluruh jumlah data. Kuintil 1 adalah kelompok rumah tangga dengan pengeluaran per kapita per bulan paling rendah (miskin) dan kuintil 5 adalah kelompok rumah tangga yang memiliki pengeluaran perkapita perbulan paling tinggi. Dari hasil olah data menggunakan SPSS didapatkan statistik kelompok pengeluaran per kapita per bulan dengan metode kuintil seperti pada tabel 1. Ditunjukkan bahwa rumah tangga miskin pada penelitian ini adalah rumah tangga yang memiliki pengeluaran per kapita per bulan 
antara Rp 237.357,14 s.d. Rp 552.348,38 yang berjumlah 110 rumah tangga sampel.

\section{Perhitungan Variabel Skor Aset Rumah Tangga}

Menghitung Skor Aset rumah tangga menggunakan metode PCA Polychoric. Komponen yang diambil hanya komponen pertama karena sudah mampu menjelaskan variasi data sebesar 58 persen, sedangkan kontribusi komponen yang lain tidak terlalu besar. Sehingga didapatkan model skor aset sebagai berikut:

$$
\begin{aligned}
\text { Aset }_{i}= & 0,39 a_{i}+0,39 b_{i}+0,42 f_{i}+0,34 g_{i}+0,28 h_{i}+ \\
& 0,40 k_{i}+0,39 l_{i}+0,13 m_{i}
\end{aligned}
$$

Berdasarkan model di atas, terlihat bahwa aset yang menyumbang nilai terbesar pada skor aset suatu rumah tangga di Kabupaten Lebong adalah kepemilikan aset berupa Komputer/laptop (f) dan kepemilikan aset berupa mobil (k).

\section{Pembentukan Model Regresi Logistik Biner}

Untuk melakukan pemodelan digunakan analisis logistik biner karena variabel dependen yaitu status kemiskinan rumah tangga adalah variabel katagorik dua kategori. Pengolahan data dilakukan dengan menggunakan SPSS.

Tabel 2 Hasil Uji Simultan

\begin{tabular}{|c|c|c|c|}
\hline \multicolumn{4}{|c|}{ Hosmer and Lemeshow Test } \\
\hline Step & Chi-square & df & Sig. \\
\hline$(1)$ & $(2)$ & $(3)$ & $(4)$ \\
\hline
\end{tabular}

\begin{tabular}{|l|l|l|l|}
\hline 1 & 9.353 & 8 & .313 \\
\hline
\end{tabular}

Tabel 3 Hasil Perhitungan R-Square

\begin{tabular}{|c|c|c|c|}
\hline \multicolumn{4}{|c|}{ Model Summary } \\
\hline Step & $\begin{array}{c}-2 \text { Log } \\
\text { likelihood }\end{array}$ & $\begin{array}{c}\text { Cox \& Snell } \\
\text { R Square }\end{array}$ & $\begin{array}{c}\text { Nagelkerke } \\
\text { R Square }\end{array}$ \\
\hline$(1)$ & $(2)$ & $(3)$ & $(4)$ \\
\hline 1 & 431.473 & .194 & .307 \\
\hline
\end{tabular}

Model regresi logistik biner yang terbentuk adalah:

$$
\begin{aligned}
& \operatorname{In}\left(\frac{p_{i}}{1-p_{1}}\right)=2,45-1,97 \text { Aset }_{i}-0,65 \text { PROPpddk }_{i^{-}} \\
& \text {2,81PROPkerja }{ }_{i} \text { 1,51JmIART }
\end{aligned}
$$

Sebagaimana hasil uji simultan menggunakan Uji Hosmer and Lameshow menunjukkan nilai $p$-value $=0.313$ yang lebih besar dari tingkat signifikansi 5 persen $(\alpha=0.05)$ sehingga keputusan yang didapat adalah gagal tolak H0. Kesimpulannya bahwa dengan tingkat kepercayaan 95 persen, model yang didapat sudah sesuai (fit).

Hasil Uji R Square dengan Nagelkerke menunjukkan bahwa 30,7 persen variasi dari rumah tangga miskin di Kabupaten Lebong dapat dijelaskan oleh variabel skor aset, proporsi ART berpendidikan tinggi, proporsi ART bekerja, dan jumlah anggota rumah tangga, sedangkan sisanya dijelaskan oleh variabel lain.

Tabel 4 Hasil Pengujian Parsial

\begin{tabular}{|l|l|c|c|c|c|c|c|}
\hline \multicolumn{7}{|c|}{ Variables in the Equation } \\
\hline \multicolumn{2}{|c|}{$(1)$} & B & S.E. & Wald & df & Sig. & Exp(B) \\
\hline \multirow{3}{*}{ Step 1 $1^{\text {a }}$} & Aset & $-1.965^{*}$ & .364 & 29.144 & 1 & .000 & .140 \\
\cline { 2 - 8 } & PROPpddk & $-.652^{* *}$ & .399 & 2.667 & 1 & .102 & .521 \\
\cline { 2 - 8 } & PROPkerja & $-2.807^{*}$ & .504 & 31.071 & 1 & .000 & .060 \\
\cline { 2 - 8 } & JmlART(1) & $-1.507^{*}$ & .284 & 28.089 & 1 & .000 & .222 \\
\cline { 2 - 8 } & Constant & $2.449^{*}$ & .442 & 30.687 & 1 & .000 & 11.580 \\
\hline
\end{tabular}

Keterangan: $*$ =signifikan pada taraf signifikansi 5 persen

** =signifikan pada taraf signifikaansi 11 persen 


\section{Analisis Variabel yang Berpengaruh dalam Model}

Pada Tabel 4 yaitu uji yang dilakukan secara parsial, dapat dilihat bahwa semua variabel signifikan berpengaruh pada taraf siginifikansi 5 persen kecuali variabel proporsi ART berpendidikan tinggi (PROPpddk) yang signifikan berpengaruh pada taraf signifikansi 11 persen (lihat kolom 6 tabel 4). Interpretasi rasio kecenderungan (odds ratio) yaitu nilai $\operatorname{Exp}(B)$ untuk masing-masing variabel bebas (independen) dapat dirincikan sebagai berikut:

\section{Nilai Intercept}

Nilai $\operatorname{Exp}(\mathrm{B})$ untuk intercept yang terbentuk dalam model adalah sebesar 11,58. Hal ini berarti bahwa rumah tangga yang di dalamnya tidak ada ART yang bekerja dan berpendidikan tinggi (PROPkerja dan PROPpddk $=0$ ), tidak memiliki aset (Aset $=$ 0), serta memiliki jumlah ART kurang dari sama dengan 4 orang memiliki kecenderungan yang besar untuk menjadi miskin yaitu sebesar 11,58 kali.

2. Variabel Skor Aset (Aset)

Rumah tangga di Kabupaten Lebong dengan nilai aset 1 poin lebih tinggi akan memiliki kecenderungan 0,14 kali untuk menjadi miskin. Atau dengan kata lain, suatu rumah tangga yang memiliki skor aset 1 poin lebih rendah memiliki kecenderungan 7,14 kali (1/Exp(B)) untuk menjadi miskin. Dengan asumsi variabel lain konstan. Hal ini sesuai dengan teori bahwa kepemilikian aset menggambarkan kekayaan suatu rumah tangga yang dapat mempengaruhi tingkat pengeluaran suatu rumah tangga ${ }^{[9]}$. Sehingga semakin tinggi nilai aset yang dimiliki suatu rumah tangga, maka semakin kecil peluang rumah tangga tersebut untuk menjadi miskin.

3. Variabel Proporsi ART Berpendidikan Tinggi (PROPpddk)

Rumah tangga di Kabupaten Lebong dengan nilai proporsi ART pendidikan tinggi 1 satuan lebih tinggi memiliki kecenderungan 0,521 kali untuk menjadi miskin. Atau dengan kata lain, suatu rumah tangga dengan proporsi ART pendidikan tinggi 1 satuan lebih rendah memiliki kecenderungan 1,92 kali $(1 / \operatorname{Exp}(B))$ untuk menjadi miskin. Dengan asumsi variabel lain konstan. Hal ini sesuai dengan teori yang disebutkan Todaro bahwa tingkat pendidikan formal yang diselesaikan oleh seseorang akan berpengaruh positif terhadap tingkat pendapatan yang diterimanya ${ }^{[10]}$. Sehingga, semakin banyak anggota rumah tangga (ART) yang berpendidikan tinggi maka peluang rumah tangga tersebut untuk menjadi miskin semakin kecil.

4. Variabel Proporsi ART Bekerja (PROPkerja) Suatu rumah tangga dengan nilai proporsi ART yang bekerja 1 satuan lebih tinggi memiliki kecenderungan 0,06 kali untuk menjadi miskin. Atau dengan kata lain, suatu rumah tangga dengan proporsi ART bekerja 1 satuan lebih rendah memiliki kecenderungan 16,67 kali $(1 / \operatorname{Exp}(B))$ untuk menjadi miskin. Dengan asumsi variabel lain konstan. Seperti yang diketahui bahwa tujuan bekerja adalah untuk mendapatkan pendapatan $^{[11]}$. Sehingga, semakin banyak orang yang bekerja dalam suatu rumah tangga maka semakin banyak pula pendapatan yang diterima rumah tangga yang berefek pada semakin kecil peluang rumah tangga tersebut untuk menjadi miskin.

5. Variabel Jumlah ART

Suatu rumah tangga yang memiliki jumlah ART lebih dari 4 orang memiliki kecenderungan sebesar 0,22 kali untuk menjadi miskin dibandingkan dengan rumah tangga dengan jumlah ART kurang dari sama dengan 4 orang. Atau dengan kata lain, rumah tangga dengan jumlah ART kurang dari sama dengan 4 orang memiliki kecenderungan 4,55 kali $(1 / \operatorname{Exp}(B))$ untuk menjadi miskin. Dengan asumsi variabel lain konstan. Hal ini bisa jadi karena semakin banyak ART dalam suatu rumah tangga, maka akan semakin tinggi pula kemungkinan ART dalam rumah tangga tersebut untuk bekerja dan berpendidikan tinggi yang berefek pada akan meningkatnya pendapatan suatu rumah tangga. Sehingga, akan memperkecil peluang rumah tangga tersebut untuk menjadi miskin. 


\section{KESIMPULAN}

Pembahasan hasil menunjukkan bahwa faktor kepemilikan aset, banyaknya ART yang bekerja dalam rumah tangga, banyaknya ART dengan pendidikan tinggi, serta banyaknya jumlah ART mempengaruhi kecenderungan rumah tangga di Kabupaten Lebong untuk menjadi miskin. Semakin mendekati 1 nilai proporsi ART yang bekerja dan proporsi ART yang berpendidikan tinggi (jumlah ART yang bekerja/berpendidikan tinggi sama dengan jumlah ART di rumah tangga tersebut) maka semakin kecil peluang suatu rumah tangga untuk menjadi miskin. Begitu juga semakin tinggi jumlah ART suatu rumah tangga, akan semakin kecil pula peluang rumah tangga tersebut untuk menjadi miskin. Hal ini mengindikasikan bahwa peningkatkan layanan pendidikan dan pembukaan lapangan kerja sebanyak-banyaknya di Kabupaten Lebong akan mampu mengurangi tingkat kemiskinan yang selama dua tahun terakhir mengalami peningkatan.

\section{DAFTAR PUSTAKA}

[1] Zuhdiyaty, N., \& Kaluge, D. (2017). Analisis Faktor-Faktor Yang Mempengaruhi Kemiskinan Di Indonesia Selama Lima Tahun Terakhir. Jurnal Ilmiah Bisnis dan Ekonomi Asia, 11(2), 27-31.

[2] Nurwati, N. (2008). Kemiskinan: Model Pengukuran, Permasalahan dan Alternatif Kebijakan. Jurnal Kependudukan Padjadjaran, 10(1), 1.

[3] BPS. (2020). Data dan Informasi Kemiskinan Kabupaten/Kota. Jakarta: BPS

[4] Marlinda, V. Y. P., \& Permanasari, V. Y. (2019). Pengeluaran out of pocket rumah tangga untuk upaya pencegahan kesehatan anak: analisis berbasis two part model dan Tobit. BKM Journal of Community Medicine and Public Health.

[5] Adiana, P. P. E., \& Karmini, N. L. (2012). Pengaruh Pendapatan, Jumlah Anggota Keluarga dan Pendidikan Terhadap Pola Konsumsi Rumah Tangga Miskin di Kecamatan Gianyar. Jurnal Ekonomi
Pembangunan Fakultas Ekonomi Universitas Udayana. Hal, 39-48.

[6] Jacobus, E. H., Kindangen, P., \& Walewangko, E. N. (2019). Analisis faktor-faktor yang mempengaruhi kemiskinan rumah tangga di Sulawesi Utara. Jurnal Pembangunan Ekonomi dan Keuangan Daerah, 19(7).

[7] Hosmer, D. W. dan Lemeshow, S.. (2000). Applied Logistic Regression. John Willey and Sons. Inc.New York.

[8] Rata-rata Pengeluaran per Kapita. (2019, August 29). SEPAKAT wiki, . Retrieved 00:37, January 24, 2021 from http://sepakat.bappenas.go.id/wiki/index.p hp?title=Ratarata_Pengeluaran_per_Kapita\&oldid $=534$.

[9] Nanga, Muana. 2005. Makro Ekonomi: Teori, Masalah, dan Kebijakan, Jakarta: PT Grafindo Persada.

[10[ Todaro, Michael. 2000. Pembangunan Ekonomi di Dunia Ketiga. Edisi Ketujuh Jilid I. Jakarta : Erlangga.

[11] Basorudin, Muhammad \& Heryanti, Rizka \& Humairo, Nadia \& Putro, Anggoro \& Firdani, Alfada. (2020). Ketenagakerjaan dan Kemiskinan. $3 . \quad 79-91$. 10.23969/oikos.v4i1.1866.

${ }^{1}$ Badan Pusat Statistik Kabupaten Lebong, siti.zf@bps.go.id 